\title{
> Gjesteskribent
}

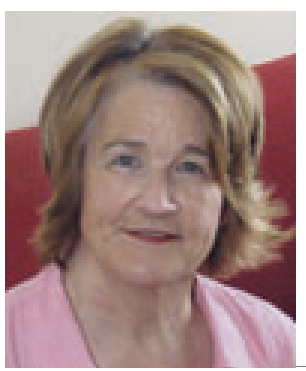

Bente Lindbæk

Sosionom, familieterapeut og høyskolelektor

\section{Hvorfor kunne ikke noen si «beklager»?}

Når fagpersonell innenfor sosialog helsevesen utsettes for alvorlig sykdom eller brå død, møtes vi ofte med forventninger fra kolleger om at vi er godt rustet til å takle situasjonen på egen hånd. Men er det slik? Min personlige erfaring er at vi i nøyaktig samme grad som andre trenger informasjon, veiledning og støtte i livets krisesituasjoner.

Ti år gammel døde min sønn Espen etter feilbehandling på sykehus. Nå, mange år senere, er jeg fortsatt opprørt over at ingen ansvarlige ga oss en forklaring eller sa «beklager». Legene skulle ha lagt alle kortene på bordet om hvorfor og hva som hadde gått galt. Familien brukte mye tid og krefter på å finne en forklaring på hvorfor Espen døde.

Mangelen på informasjon og faglig oppfølging forsinket sorgarbeidet for hele familien i mange år. Først nå, etter over $20 \stackrel{\circ}{r}$, føler jeg at jeg og min familie kan leve godt med sorgen.

Når det verste skjer, er det helt avgjørende at de pårørende får god og konkret informasjon om sykdomsforløpet og om hvordan man kan få hjelp til å bearbeide sorgen. Ord og handlinger etses inn i hukommelsen og blir der resten av livet. I vår situasjon førte dårlig kommunikasjon til en forsinket sorgreaksjon både for hver enkelt og for familien samlet.

Da vi ble kontaktet av én av fem mulige leger en uke etter dødsfallet, sa vedkommende: «Du som er fagperson klarer vel dette selv.» Det slår ekstra hardt å oppleve dette når man selv er fagperson/helsepersonell. Man blir møtt med forventningen om at man skal takle slike ekstreme situasjoner på en bedre måte enn andre fordi man har en faglig bakgrunn. Sånn tror jeg ikke det er, man stoler kanskje mindre på magefølelsen og har lettere for å intellektualisere situasjonen - «man skal klare det selv». Vi var alle i sjokk og kunne dra lite nytte av tidligere kunnskap. Som pårørende flest trengte vi sårt til god legeinformasjon for å takle situasjonen.

Det å være pårørende og mor med forventninger fra fagpersonell om å klare det meste selv, ble en ekstra byrde - det var som om jeg og familien ikke var «kvalifisert» for øyeblikkelig hjelp. Det tok et par år før jeg fant veien til psykolog. Da var alle i familien begynt å gå i hver sin retning. Min mann og jeg ble senere skilt, og begge de to gjenlevende sønnene våre trengte faglig hjelp på et senere tidspunkt. Vi har nå over 20 års sorgarbeid bak oss.

Vi fikk erfare at måten foreldre blir ivaretatt på ved et barns død kan ha livslange konsekvenser for både foreldre og søsken. På det tidspunkt Espen var inn og ut av sykehus var det tre psykologer ansatt som vi aldri ble henvist til.

Et tilbakevendende aktuelt tema i mediene er legers evne til god kommunikasjon i de vanskelige pasientsamtalene.
Tre av fire klagesaker handler om dårlig kommunikasjon. Jeg mener ut fra egne erfaringer at her er det et forbedringspotensial. Det kreves trening og atter trening for blant annet å beherske de vanskelige samtalene rundt liv og $\mathrm{d} \varnothing \mathrm{d}$.

Hvor mye vektlegges sorg og sorgarbeid i legestudiet? Sorgsamtaler er slitsomt, og sorg tar tid. Naturlig nok blir vi påvirket selv i disse samtalene, og egen sorgproblematikk dukker ofte opp. I en travel legehverdag er det vanskelig å finne tid til dette. Det viktige for oss klienter er å bli sett og hørt der og da, og - hvis det er nødvendig - overføres til personell som kan ta seg av videre vurderinger, eventuelt henvisning.

Etter å ha mistet et barn kan mange havne i en sørgende usynlig gruppe som ikke kommer videre i livet på grunn av senreaksjoner og forsinket sorgarbeid. Ikke minst kan dette gjelde søsken, som er lite påaktet. Er pårørende en salderingspost?

En annen kjepphest jeg har, er at når vi som fagpersoner står i slike sammensatte og kompliserte saker, er god veiledning av kolleger et must. Hvor mye ettersamtaler får leger etter dødsfall, katastrofer etc.?

20 år er for lang tid for å komme på plass igjen etter et slikt tap. Det vet jeg at Espen ikke ønsket. Som mor og etterlatt håper jeg at slike temaer får god plass i embetsstudiet og videreutdanningen for leger.

\section{Bente Sindbalk}

